\title{
Effect of political extremism on the link between the feeling of threat to group's image and intergroup hostility: The case of the expressions Tontinards and Sardinards in the Cameroonian context
}

\author{
Gustave Adolphe MESSANGA, Sabine Flore NGASSOM PENTCHEU, \& Sonia NPIANE NGONGUEU \\ Department of Philosophy-Psychology-Sociology, University of Dschang, Cameroon
}

\begin{abstract}
This study analyzes the effect of political extremism on the link between the feeling of threat to group's image and intergroup hostility. It tests the hypothesis that political extremism has a moderating effect on the link between the feeling of threat to group's image and intergroup hostility. Research methodology consisted on the administration of the scales of political extremism (Dono et al.,2018), threat to group's image, and intergroup hostility (Schaafsma \& Kipling, 2012) to 397 participants, including 221 Bamiléké and 176 Béti whose age varies between 17 and 59 years $(M=28.05$; S.D. $=8.32)$. The results of the statistical analyzes provide empirical support for the hypothesis of the study. We conclude that this study contributes to the literature on the explanatory factors of intergroup hostility by revealing that the link between that construct and threat to group's image is moderated by political extremism.
\end{abstract}

Keywords: Political extremism; feeling of threat to group's image; intergroup hostility; Tontinards; Sardinards.

\section{INTRODUCTION}

$\mathrm{I}^{\mathrm{r}}$ ntergroup threat theory proposes that members of a group feel threat when they adhere to the idea that another group is capable of causing them harm (Stephan \& Stephan, 2000). It distinguishes four forms of threat that can be used to predict prejudice against outgroups: realistic and symbolic threats, intergroup anxiety and negative stereotypes. The concept of realistic threat derives from the Realistic Conflict Theory which proposes that competition between groups for the access to limited resources can be at the origin of prejudices against other groups (Stephan \& Renfro, 2002). In this logic, the realistic threat arises from the feeling that outgroups are in the position to attack ingroup's life, material resources or power. The symbolic threat, on the other hand, is felt when outgroup dishonors, dehumanizes and devalues ingroup (Cameron et al., 2005). It arises because ingroup believes in the moral correctness of its own belief system (Stephan \& Stephan, 2000) and fears that the new norms and beliefs defended by the outgroup will jeopardize its way of life. Intergroup anxiety involves psychological states such as embarrassment, rejection, discrimination or negative evaluation of outgroup's members (Stephan \& Stephan, 1985). Stereotypes are a collection of characteristics, including traits, attitudes, behaviors, and goals that are associated with members of a social category (Campbell \& Mohr, 2011). Those with a negative valence may be at the root of stigma and negative attitudes towards targeted outgroups (Hamilton et al., 1990). Indeed, the mere knowledge of demeaning stereotypes about oneself or about the group could make the people who are its victims feel a threat to group'simage (Major \& O'Brien, 2005).

The threat to group's image

According to Blumer (1958), the feeling of threat to group's image is the worry that members of a dominant group have over a dominated outgroup. The literature reveals that prejudices, stereotypes and discriminatory attitudes are its consequences (Dambrun \& Guimond, 2001). Prejudice consists of a negative attitude or predisposition to adopt a negative behavior towards a group or towards the members of that group, which is based on an erroneous and rigid generalization (Bourhis et al., 1999). They can generate a feeling of threat among members of targeted groups. According to the specialized literature, this feeling is mediated by three factors, including identification with a group (Morrison \& Ybarra, 2008); group attachment and glorification (Roccas et al., 2006). The first factor reinforces ethnic prejudices (Morrison et al., 2010), political conservatism and political envy (Major et al., 2018). The second emphasizes responses to a threat related to group's image. The third can push individuals to adopt extreme behaviors in the face of the danger represented by an outgroup (Steele et al., 2015). Theseantecedents can be the sources of various forms of threat leading to certain responses, including intergroup hostility.

\section{Threat to group's image and intergroup hostility}

The needs for affiliation, assessment and appreciation are felt by each individual; hence they can be considered normal (Baumeister \& Leary, 1995). However, these needs can be marred by value judgments that can generate a feeling of rejection (Marques \& Paez, 1994). As soon as these side effects take hold and tarnish a group's image, its members display negative behaviors to enhance it (Nugier et al., 2003). 
It is in this logic that Adorno et al. (1950) assert that the feeling of difference turns into a feeling of threat and an attitude of hostility.

The link between group threat and intergroup hostility has been explored in the context of sexual orientation (Crandall, 1994). It emerges that heterosexuals and homosexuals develop hostility towards each other because each group wants to give importance to its values and sexual practices to the detriment of those of the outgroup (Wyman \& Snyder, 1997). This is because individuals and groups face threats by adopting hostile attitudes towards outgroups and supporting actions that can harm their members, with the aim of reducing their power, worth and esteem (Morrison \& Ybarra, 2008). Indeed, the literature compiled so far confirms the links between threat to group's image and intergroup attitudes (Corenblum \& Stephan, 2001). It indicates that when individuals feel a threat to their group's image,they develop hostile behaviors towards outgroup in various domains, including politics, which is the main focus of this research. Some of these behaviors may reveal extremist tendencies, constitutive of political extremism.

\section{Political extremism and intergroup hostility}

Political extremism is a radical stand against the political positions and values of a society, rejecting any form of pluralism (Pfahl-Traughber, 2017). It is characterized by the rejection of the democratic rule of law (Baier, 2018), attacks aimed at modifying or even suppressing the constitutional order, demography (Goertz \& Goertz-Neumann, 2018) and the manifestation of political enmity with violence and hostilities (Franz, 2013). This is a phenomenon leading to an absolute rejection of political and democratic solutions to meet the various demands (Busby, 2018). It is a preliminary process or phase that prepares its supporters for hostility (Bjørgo, 2002). The World-Saver model or "added-value system" of political extremism identifies three factors of violence, including the development of antipathy towards a target group; creating warrant justifications for violent actions; and removal of social and psychological barriers (Kilbourne \& Richardson, 1989, cited by Borum, 2012). Political extremism cannot be seen as the product of a single decision, but rather the final result of a dialectical process gradually pushing its followers to violence (McCormick, 2003).

Membership in extremist political groups is justified by ideological arguments (Busby, 2018). Political extremism offers individuals answers to existential questions, active political responses to injustice, and feelings of belonging (Fermin, 2009). Canetti-Nisim et al. (2009) argue that political extremists are predominantly representative and seek to exclude their minority political opponents by employing strategies such as injustice for example (Coenders \& Scheepers, 2003). These minority political adversaries, despite having little power and resources, could develop hostile attitudes and behaviors towards the majority group. The literature reveals that political extremism leads to intolerance, conflict and aggression (Horgan, 2005). It designates a process by which the individual moves from discourse to action, that is, from radicalization to violence (Anthony, 2015). To achieve the goals they set for themselves, political extremists are said to use discrimination, stereotypes and other means characterized by contempt and violation of human rights and freedoms (Neuman, 2010). In the Cameroonian political context, the stereotypes revealed by the names Tontinards and Sardinards fall into this register. They can therefore generate intergroup hostility.

Effect of political extremism on the link between the feeling of threat to group's image and intergroup hostility: The case of the expressions Tontinards and Sardinards in the Cameroonian context

The post-electoral crisis that Cameroon experienced after the presidential elections of October 2018 led to the appearance of two terms that are currently well established in the vocabulary of the citizens of this country: Sardinards and Tontinards (Cameroon Web, November 13, 2018). These disparaging terms were coined to refer to two groups of politically opposed citizens. The term Sardinards reflects the gluttony ofthe members of the ruling class and their supporters who are more concerned with food and drink than political ideas and agendas (Cameroon voice, November 11, 2018). The term Tontinards, meanwhile, refers to individuals who defend the ideas of President Paul Biya's main challenger in the last presidential elections and support him in the conquest of power (Banen du Benelux, April 17, 2019). At first glance, these two notions, created in the political sphere, seem to emerge exclusively from the political register. But, one must go beyond this first impression. Indeed, over time, they have taken ethnic connotations (Le Soir Trihebdo, March 11, 2020).

The term Sardinards is political from the outset, as it designates a political group made up of the supporters and sympathizers of the existing system (AFRIC, July 15, 2019). They are individuals who regularly receive sardine and bread during political meetings preparatory to electoral competitions and who, voluntarily or not, would collaborate in the maintenance of the current political system in Cameroon (Quatrième Pouvoir, November 11, 2018). This concept is then a practice which is specific toa political party and therefore has a purely political connotation (Journal d'Afrique, November 11, 2018). However, although used in the political sphere, the term Tontinards, created in response to that of Sardinards, seems not to be confined to this sphere. Indeed, this concept having as radical the word tontine, a rotating savings system well known in Cameroon, does not refer to a practice which is specific to the political family of Maurice Kamto, Paul Biya'smain challenger in the October 2018 presidential election. It refers more to a specific characteristic of his ethnic group of origin: the Bamiléké (Banen du Benelux, April 17, 2019). Thus, the fact that the term Tontinards has an ethnic rather than a political 
connotation has also helped to ethnicize the term Sardinards (Journal d'Afrique, November 11, 2018). It is this name, which designates a specific ethnic group, that migrated these two concepts from the political to the ethnic sphere (Cameroon Web, November 13, 2018). Concretely, the name Tontinards refers to the Bamiléké (Cameroon Voice, November 11,2018), people whose main activity is trade and who saves the money they earn in tontines (Quatrième pouvoir, November 1, 2018). The Bamiléké are considered as people with communitarian tendencies, who advocate the defense of common interests (Quatrième pouvoir, November 2 , 2018). The conceptof Sardinards, meanwhile, now refers to the Béti and their related ethnic groups (and no longer just members and supporters of the ruling party). Béti are stereotyped as enjoyers who love luxury, laziness, ease, and the pleasures of the stomach and lower abdomen (Cameroon Web, November 13, 2018; Onana Onomo, 2002). The two terms that this research is interested in consist of ethnocentric, demeaning and degrading prejudices based on Bamiléké and Béti ethnicities. They could therefore generate intergroup hostility (Abrams \& Hogg, 1988). Indeed, if we refer to the fact that these two groups were opposed for the conquest of power in the 2018 presidential elections, through the two main candidates who are their members, we can understand that they could develop hostile attitudes one towards the other; the literature revealing in this perspective that intergroup competition generated by the desire to capture scarce resources leads to intergroup hostility (Esses et al., 2001).

The literature lists several explanatory factors for intergroup hostility (Halpern \& Weinstein, 2004). Among them, we can cite: prejudices (Branscombe \& Wann, 1994); attachment (Critchfield et al., 2008); political extremism (Bjørgo, 2002); and threat to group's image (Morrison \& Ybarra, 2008). The latter is felt when the group believes in the moral correctness of its own belief system (Stephan \& Stephan, 2000) and fears that the norms and beliefs of the outgroup endanger its way of life. Previous work reveals the existence of a link between a feeling of threat to group's image and intergroup hostility (Stephan \& Renfro, 2002). In fact, individuals who perceive the threat to group's image adopt hostile attitudes towards threatening groups in an attempt to reduce their powers, values and self-esteem. According to Strabac and Listhaug (2008), this link can be influenced, on one hand, by structural variables such as social hierarchy (Schneider, 2008) and by contextual and individual variables, such as the environment (Bouffard \& Mariné, 2004), on the other hand. In this sense, the literature has identified moderating factors of the link between the feeling of threat to group's image and intergroup hostility. These factors include intergroup bias, intergroup contact and collective narcissism (Golec de Zavala et al., 2013a). But, itis yet to shed light on the role of political extremism as a moderating factor of this relationship, in a theoretical context where it is suggested that political extremism, linked to conflict, aggression, violence and intolerance could also impact the link between the feeling of threat to group's image and intergroup hostility (Goertz \&
Goertz-Neumann, 2018). In this vein, the scientific project of this study is to analyze the effect of political extremism on the link between thefeeling of threat to group's image and intergroup hostility.

\section{HYPOTHESIS}

The thesis defended by this study and which constitutes its theoretical contribution is as follows: political extremism has a moderating effect on the link between the feeling of threat to group's image and intergroup hostility.

\section{METHOD}

\section{Participants}

397 participants of both sexes (185 men and 212 women), including 221 Bamiléké and 176 Béti took part in this study. The choice of these participants was motivated by the fact that the terms Tontinards and Sardinards refer respectively to members of the Bamiléké and Béti ethnic groups. They are students enrolled in various faculties of the Universities of Dschang and Yaoundé 1 (Cameroon). Their age is between 17 and 59 years $(\mathrm{M}=28.05 ; \mathrm{SD}=8.32)$.

\section{Material and procedure}

Three instruments were used in the present study to collect data from participants : scales of political extremism (Dono et al., 2018), threat to group's image designed for the purposes of this research, and intergroup hostility (Schaafsma \& Kipling, 2012). The task of the participants was to score their levels of agreement or disagreement for the items of each of these instruments of data collection on a 6-points Likert scale, ranging from 1 (Strongly disagree) to 6 (Strongly agree).The scale of political extremism has been adapted to the Cameroonian social context. Originally constructed in the English language, it was translated into French for this research. For example, item 1 worded as "My ideas are socially much fairer than those of my political adversaries" became "Mes idées sont socialement beaucoup plus justes que celles de mes adversaires politiques." This instrument comprises 8 items equally divided into two dimensions: cognitive and behavioral. It has an acceptable and satisfactory internal consistency index $(\alpha=.72)$. The assessment of the feeling of threat to group's image was done using a twodimensional scale devoted one to the Bamiléké and the other to the Béti $(\alpha=.84)$. Each contains 8 items, all coded in the right side. In the version of the scale addressed to the Bamiléké, item 1 reads as follows: "The Béti go to political meetings just for a T-shirt."In the version addressed to the Béti, item 1 proposes that:"The Bamileke prefer to travel kilometers to go to their brothers'shops to consume, so that the money stays with the family.'The intergroup hostility scale has been adapted in French and for the two groups. This instrument contains 7 items and has a satisfactory internal consistency index $(\alpha=.78)$. For example, in the version addressed to Béti, item 1 reads as follows: "I would like to hurt Bamiléké." 


\section{RESULTS}

The results of this study are presented in two stages: first, a descriptive (means and standard deviations) and correlational analysis is carried out. Then regression analyzes are done.

Table 1: Descriptive and correlational statistics between political extremism, threat to group's image and intergroup hostility

\begin{tabular}{|c|c|c|c|c|c|}
\hline & Mean & $\begin{array}{c}\text { Standard } \\
\text { deviation }\end{array}$ & 1 & 2 & 3 \\
\hline 1. Political extremism & 27,9043 & 5,88792 & 1 & & \\
\hline 2.Threat to group's image & 29,7683 & 8,69760 & $.482^{* *}$ & 1 & \\
\hline 3. Intergroup hostility & 19,3409 & 7,64877 & $.366^{* *}$ & $.345^{* *}$ & 1 \\
\hline
\end{tabular}

**. The correlation is significant at the 0.01 level (two-tailed).

Table 1 presents descriptive (means and standard deviations) and correlational statistics of the links between political extremism, feeling of threat to group's image and intergroup hostility. We observe that the participants present scores above the average on the measures of political extremism (M $=27.904>24 ;$ S.D. $=5.887)$ and threat to group's image $(\mathrm{M}=$ 29.768> 24; S.D. $=8.697)$. However, their score is below average on the measure of intergroup hostility $(\mathrm{M}=19.34$ $<21$; S.D. = 7.648). The data collected also indicate that there are positive and significant correlations between political extremism and intergroup hostility $(r=.366 ; \mathrm{p}<.01)$; between political extremism and threat to group's image $(r=.482 ; \mathrm{p}$ $<.01$ ); and between threat to group's imageand intergroup hostility $(\mathrm{r}=.345 ; \mathrm{p}<.01)$. They confirm the fact that there is, on one hand, a link between the feeling of threat to group's image and intergroup hostility and, on the other hand, a link between political extremism and intergroup hostility. To know the effect of political extremism on the link between the feeling of threat to group's image and intergroup hostility, a regression analysis is necessary.
Table 2: Regression and moderation statistics between the threat to group's image, political extremism and intergroup hostility

\begin{tabular}{|c|c|c|c|c|c|c|c|}
\hline & \multirow{2}{*}{\multicolumn{2}{|c|}{ Modèle }} & \multicolumn{2}{|c|}{$\begin{array}{l}\text { Standardized } \\
\text { Coefficients }\end{array}$} & $\begin{array}{c}\text { Non } \\
\text { standardized } \\
\text { Coefficients }\end{array}$ & \multirow[t]{2}{*}{$\mathrm{T}$} & \multirow[t]{2}{*}{ Sig. } \\
\hline & & & B & $\begin{array}{l}\text { Standar } \\
\text { d error }\end{array}$ & Bêta & & \\
\hline \multirow{2}{*}{1} & \multicolumn{2}{|c|}{ (Constant) } & 10.209 & 1.351 & & 7.555 & .000 \\
\hline & \multicolumn{2}{|c|}{$\begin{array}{l}\text { Total threat to } \\
\text { group's image }\end{array}$} & .272 & .039 & .333 & 7.016 & .000 \\
\hline \multirow{3}{*}{2} & \multicolumn{2}{|c|}{ (Constant) } & 4.065 & 1.783 & & 2.279 & .023 \\
\hline & \multicolumn{2}{|c|}{$\begin{array}{l}\text { Total threat to } \\
\text { group's image }\end{array}$} & .167 & .043 & .205 & 3.891 & .000 \\
\hline & \multicolumn{2}{|c|}{$\begin{array}{c}\text { Political extremism } \\
\text { total }\end{array}$} & .347 & .068 & .267 & 5.081 & .000 \\
\hline & & \multirow{2}{*}{$\begin{array}{l}\text { Bêta } \\
\text { In }\end{array}$} & \multirow{2}{*}{$\mathrm{T}$} & \multirow{2}{*}{ Sig. } & \multirow{2}{*}{$\begin{array}{l}\text { Partial } \\
\text { correlation }\end{array}$} & \multicolumn{2}{|c|}{$\begin{array}{l}\text { Colinearity } \\
\text { statistics }\end{array}$} \\
\hline & & & & & & \multicolumn{2}{|c|}{ Tolerance } \\
\hline \multicolumn{2}{|r|}{$\begin{array}{l}\text { Political } \\
\text { extremism total }\end{array}$} & $.267^{\mathrm{b}}$ & 5.081 & .000 & .248 & \\
\hline
\end{tabular}

a. Dependent variable: Total intergroup hostility; b. Predictors in the model: (Constant), Total threat to group's image.

Table 2 shows that the feeling of threat to group's image has a positive and significant effect on intergroup hostility $(\beta(\mathrm{N}=$ $3971)=.333 ; \mathrm{t}=7.555 ; \mathrm{p}<.05)$. When we introduce the moderating variable of this link, which is political extremism, we observe that it affects the intensity of the effect initially observed $(\beta(\mathrm{N}=397)=.267 \mathrm{~b} ; \mathrm{t}=5.081 ; \mathrm{p}<.05)$. We then see a fluctuation in the effect of the feeling of threat to group's image on intergroup hostility when the political extremism'sfactor is integrated into this relationship. In conclusion, political extremism affects the link between the feeling of threat to group'simage and intergroup hostility. This moderating effect can be seen through the summary diagram below:

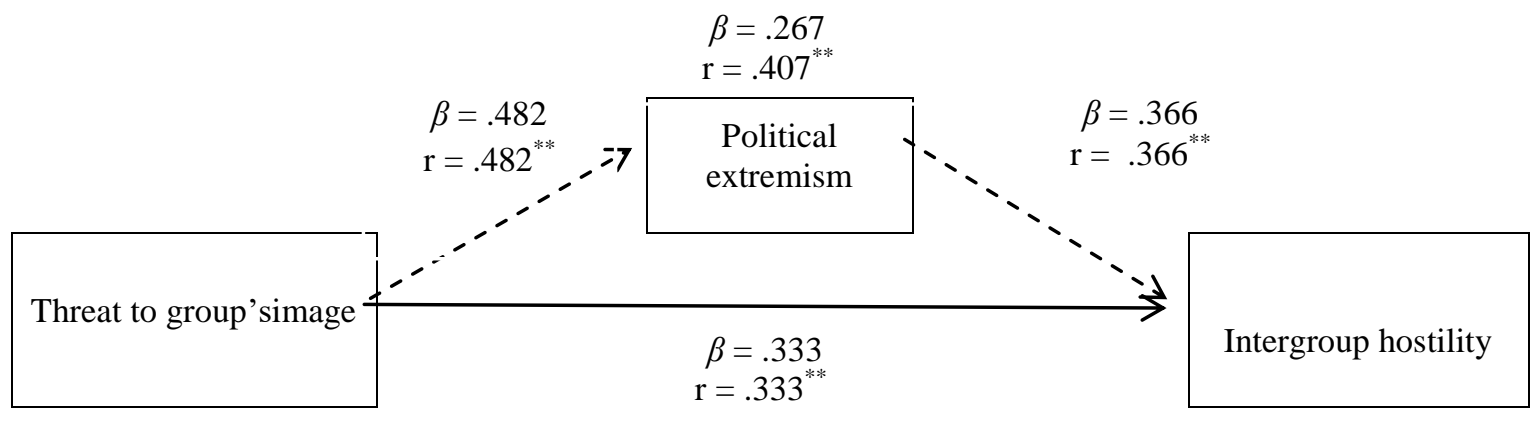

Figure 1: Summary of the moderating effect of political extremism on the link between the feeling of threat to group's image and intergroup hostility

\section{DISCUSSION}

This study tests the hypothesis that political extremism has a moderating effect on the link between the feeling of threat to group's image and intergroup hostility. The results obtained provide empirical support for this prediction, showing that political extremism affects the quality of the link between the feeling of threat to group'simage and intergroup hostility. They agree with intergroup threat theory (Stephan \& Stephan, 2000), which postulates that the feeling of threat generates prejudice and the degradation of intergroup contactand 
relations. The present study also follows the logic of studies which show that political extremism (characterized by nondemocracy, hate speech, one-party rule, devaluation of outgroups and intimidation) leads to hostility (Eser Davolio \& Lenzo, 2017). Indeed, individuals who belong to political groups with extreme positions campaign for radicalization (Fermin, 2009; Neumann \& Rogers, 2007), intolerance, conflict, violence and aggression (Horgan, 2005), and are predisposed to intergroup hostility.

Political extremists would use intergroup hostility as a strategy to protect and restore their image in order to reduce the perceived threat for the group. In this vein, the theory of threatened egotism shows that political extremists invest emotionally to enhance the image of their group and use hostility to retaliate against those who, willfully or not, tarnish their image (Bushman \& Baumeister, 1998). Self or group image is an absolute good that facilitates the resolution of a wide variety of conflicts (California Task Force, 1990). Thus, low self or group esteem is a cause of intergroup hostility and inclination towards extreme groups (Kirschner, 1992). Threatened egotism reveals that vulnerability to group threat facilitates membership in violent groups and leads to intergroup hostility (Bushman \& Baumeister, 1998). Individuals or groups with strong or positive values feel more threat to their group's image and, as a result, are more predisposed to intergroup hostility (Baumeister et al., 1996).

The results of this study can also be supported by Kernis et al.'s (1989) work which shows that individuals with high and unstable self-esteem tend to be more hostile than those with stable and high self-esteem. Indeed, the former could be assimilated to individuals with a high feeling of threat to group's image, hence the increase in hostility. Thus, instability would produce an increased feeling of threat to group's image, because the individual is vulnerable to outgroups' threat, which predisposes him to hostility (Kernis et al., 1993) and political extremism.

\section{REFERENCES}

[1] Abrams, D., \& Hogg, M. A. (1988).Comments on the motivational status of self-esteem in social identity and intergroup discrimination.European Journal of Social Psychology, 18, 317334.

[2] Adorno, T. W., Frankel-Brunswick, E., Livinson, D. J., \& Stanford, R. N. (1950).The authoritarianpersonality. Harper.

[3] AFRIC. (15 Juillet 2019). Cameroun : la «BAS» peut-elle devenir le garant de la bonne gouvernance peu importe le pouvoir en place?

[4] Anthony, R. (2015). From terrorism to "radicalization" to "extremism": counterterrorism imperative or loss of focus? International Affairs, 91(2), 371-80.

[5] Baier, D. (2018). Gewalt und Radikalität-Forschungsstand und Prävention sperspektiven. Gutachten für den 23. Deutschen Prävention stag in Dresden.

[6] Baumeister, R. E, Smart, L., \& Boden, J. M. (1996). Relation of threatened egotism to violence and aggression: The dark side of high self-esteem. Psychological Review, 103, 5-33.

[7] Baumeister, R. F., \& Leary, M. R. (1995). The need to belong: Desire for interpersonal attachments as a fundamental human motivation. Psychological Bulletin, 117, 497-529.
[8] Banen du Benelux. (17 avril 2019). Beti-sardinards, BamilekeTontinards : Le tribalisme refait surface au Cameroun.

[9] Bjørgo, T. (2002).Exit Neo-Nazism. Reducing recruitment and promoting disengagement from racist groups. Norwegian Institute of International Affairs.

[10] Blumer, H. (1958). Race Prejudice as a Sense of Group Position.Pacific SociologicalReview, 1, 37.

[11] Borum, R. (2012). Radicalization into violent extremism I: A review of social science theories. Journal of Strategic Security, 4 (4), 7-36. https//doi.org/10.5038/1944-0472.4.4.1

[12] Bouffard, T., \& Mariné, C. (2004).Interdépendance des caractéristiques individuelles et contextuelles dans la motivation à apprendre. Revue des sciences de l'éducation, 30 (1). https//doi.org/10.7202/011766ar

[13] Bourhis, R. Y., Gagnon, A., \& Moïse, L. C. (1999). Discriminations et relations intergroupes. In R. Y. Bourhis \& J. P. Leyens (Eds.), Stéréotypes, discrimination et relation intergroupes. Mardaga.

[14] Branscombe, N. R., \& Wann, D. L. (1994). Collective self-esteem consequences of outgroup derogation when a valued social identity is on trial. European Journal of Social Psychology, 24, 641-657.

[15] Busby, M. (2018).UK has not 'woken up' to far-right threat, says ex-counter-terror chief. The Guardian.

[16] Bushman, B. J., \& Baumeister, R. (1998). Threatened egotism, narcissism, self-esteem, and direct and displaced aggression: Does self-love or self-hate lead to violence? Journal of Personality and Social Psychology, 75, 219-229. https//doi.org/10.1037/00223514.75.1.219

[17] California Task Force to Promote Self-Esteem and Personal and Social Responsibility. (1990). Toward a state of self-esteem. California State Department of Education.

[18] Cameron, J. E., Duck, J. M., Terry, D. J., \& Lalonde, R. N. (2005). Perceptions of self and group in the context of a threatened national identity: A field study. Group Processes and Intergroup Relations, 8, 73-88.

[19] Cameroon voice (18 novembre, 2018). Opinion- Cameroun: "Sardinards" Vs "Tontinards" Quand Cabral Libii se trompe volontairement de définition(s).

[20] Cameroun Web. (13 Novembre 2018). Affaire de 'Sardinards': la violente réaction de Cabral Libii.

[21] Campbell, M. C., \& Mohr, G. S. (2011). Seeing is eating: How and when activation of a negative stereotype increases stereotypeconductive behaviour. Journal of Consumer Research, 38, 431444.

[22] Canetti-Nisim, D., Halperin, E., Sharvit, K., \& Hobfoll, S. E. (2009). A New Stress-Based Model of Political Extremism: Personal Exposure to Terrorism, Psychological Distress, and Exclusionist Political Attitudes. Journal of Conflict Resolution, 10, 353-363. https//doi.org/1177/0022002709333296

[23] Coenders, M., \& Scheepers, P. (2003). The effect of education on nationalism and ethnic exclusionism: an international comparison. Political Psychology, 24(2), 313-343.

[24] Corenblum, B., \& Stephan, W. G. (2001). White fears and native apprehensions: An integrated threat theory approach to intergroup attitudes. Canadian Journal of Behavioral Science, 33, 251-268.

[25] Crandall, C. S. (1994). Prejudice against fat people: Ideology and self-interest. Journal ofPersonality and Social Psychology, 66, 882-894.

[26] Critchfield, K. L., Levy, K. N., Clarkin, J. F., \& Kernberg, O. F. (2008). The relational context of aggression in borderline personality disorder: using adult attachment style to predict forms of hostility. Clinical Psychology, 64 (1), 67-82.

[27] Dambrun, M., \& Guimond, S. (2001).La théorie de la privation relative et l'hostilité envers les Nord Africains. Revue Internationale de Psychologie Sociale, 14, 57-89.

[28] Dono, M., Alzate, M., Seoane, G, \& Sabucedo, J. M. (2018). Development and validation of the Monopoly on Truth Scale.A measure of political extremism.Psicothema, 30 (3), 330-336. https//doi.org/10.7334/psicothema2017.423 
[29] Eser Davolio, M., \& Lenzo, D. (2017).Radikalisierung\&Extremismus.Gallen.

[30] Fermin, A. (2009). Islamitischenextreem-rechtseradicaliseirng in Nederland: Eenvergelijkendliteratuuronderzoek. Risbo Research Training Consultancy.

[31] Franz, E. S. (2013). Political Attitudes of Students of Russian Universities.Sociological Studies 1, 63-78.

[32] Halpern, J., \& Weinstein, H. M. (2004)."Rehumanizing the Other: Empathy and Reconciliation". Human Rights Quarterly, 26 (3), 561-583.

[33] Goertz,

S., \&

Goertz-Neumann, M. (2018).Politischmotivierte Kriminalitätund Radikalisierung.Müller GmbH.

[34] Golec de Zavala, A., Cichocka, A., \& Iskra-Golec, I. (2013a). Collective narcissism moderates the effect of in-group image threat on intergroup hostility. Journal of Personality and Social Psychology, 104, 1019-1039.

[35] Halpern, J., \& Weinstein, H. M. (2004)."Rehumanizing the Other: Empathy andReconciliation". Human Rights Quarterly, 26 (3), 561-583.

[36] Hamilton, D. L., Sherman, S. J., \& Ruvolo, C. M. (1990). Stereotype-based expectancies: Effects on information processing and social behavior. Journal of Social Issues, 46, 35-60.

[37] Horgan, J. (2005). The Psychology of Terrorism.Routledge.

[38] Journal d'Afrique. (11 Novembre 2018). Cameroun : quel est ce mouvement de la diaspora qui boycotte les artistes soutenant Paul Biya?

[39] Kernis, M. H., Cornell, D. P., Sun, C. R., Berry, A., \& Harlow, T. (1993). There's more to self-esteem than whether its high or low: The importance of stability of self-esteem. Journal of Personality and Social Psychology, 65, 1190-1204.

[40] Kernis, M. H., Grannemann, B. D., \& Barclay, L. C. (1989).Stability and level of self-esteem as predictors of anger arousal and hostility.Journal of Personality and Social Psychology, 56, 1013-1022.

[41] Kirschner, D. (1992). Understanding adoptees who kill: Dissociation, patricide, and the psychodynamics of adoption. International Journal of Offender Therapy and Comparative Criminology, 36, 323-333.

[42] Le Soir Trihebdo.(Mercredi 11 Mars 2020). Déstabilisation du Cameroun:AtangaNji dénonce le complot des ONG contre l'État $\left(\mathrm{N}^{\circ} 1010\right.$, pp.3-5)

[43] Major, B., \& O'Brien, L. T. (2005).The social psychology of stigma.Annual Review of Psychology, 56, 393-421.

[44] Major, B., Blodorn, A., \& Major Blascovich, G. (2018).The threat of increasing diversity: Rediscovering the Social Group: A SelfCategorization Theory. Blackwell.

[45] Marques, J. M., \& Paez, D. (1994). L'effet "mouton noir " : Catégorisation sociale, rejet des écarts endogroupes et perception de la variabilité des groupes. Revue Européenne de la psychologie sociale, 5 (1), 37-68.

[46] McCormick, G. H. (2003). "Terrorist Decision Making”. Annual Review of Political Science 6, 473-507.

[47] Morrison, K. R., \& Ybarra, O. (2008). The effects of realistic threat and group identification on social dominance orientation.Journal of Experimental Social Psychology, 44 (1), 156-163.
[48] Morrison, K. R., Plaut, V. C., \& Ybarra, O. (2010). Predicting whether multiculturalism positively or negatively influences White Americans' intergroup attitudes: The role of ethnic identification.Personality and Social Psychology Bulletin, 36 (12), 1648-1661.

[49] Neuman, P. (2010). Prisons and Terrorism Radicalisation and Deradicalisation in 15 Countries. A policy report published by the International Centre for the Study of Radicalisation and Political Violence (ICSR), 12.

[50] Neumann, P. R., \& Rogers, B. (2007).Recruitment and Mobilisation for the Islamist Militant Movement in Europe.The International Centre for the Study of Radicalization and Political Violence.

[51] Nugier, A., Niedenthal, P. M., Brauer, M., \& Chekroun, P. (2003). Moral and angry emotions provoked by informal social control. Cognition and Emotion, 21 (8), 1699-1720.

[52] Onana Onomo, J.P. (2002). Symétries hégémoniques BétiBamiléké et rivalités politiques au Cameroun.CIREPE.

[53] Pfahl-Traughber, A.(2017). Der Erkenntnisgewinn der vergleichenden Extremismusforschung: Be-sonderheiten, Entwicklung, Prognosen und Ursachen. In R. Altenhof, S. Bunk, \& M. Piepenschneider (Hrsg.), Politischer Extremismusim Vergleich.Beiträgezur politischen Bildung (pp. 45-73).LIT-Verlag.

[54] Quatrième Pouvoir. (11 Novembre 2018, 08h09'). Tontinards/ Sardinards: Comprendre les nouvelles tribus de Cameroun en 11 points.

[55] Roccas, S., Klar, Y., \& Liviatan, I. (2006). The paradox of groupbased guilt: modes of national identification, conflict vehemence, and reactions to the in-group's moral violations. Journal of Personality and Social Psychology, 9 (4), 698-711.

[56] Schaafsma, J., \& Kipling, D.W. (2012).Exclusion, intergroup hostility, and religious fundamentalism.Journal of Experimental Social Psychology, 48, 829-837.

[57] Schneider, S. L. (2008). Anti-immigrant attitudes in Europe: Outgroup size and perceived ethnic threat. European Sociological Review, 24, 53-67.

[58] Steele, R. R., Parker, M. T., \& Lickel, B. (2015). Bias within because of threat from outside: The effects of an external call for terrorism on anti-Muslim attitudes in the United States. Social Psychological and Personality Science, 6 (2), 193-200.

[59] Stephan, W. G., \& Renfro, L. C. (2002). The role of threat in intergroup relations. In D. M. Mackie \& E. R. Smith (Eds.), From prejudice to intergroup emotions: Differentiated reactions to social groups (pp. 191-207). Psychology Press.

[60] Stephan, W.G., \& Stephan, C.W. (1985).Intergroup anxiety. Journal of Social Issues, 41, 157-175.

[61] Stephan, W. G., \& Stephan, C. W. (2000). An integrated threat theory of prejudice. In S. Oskamp (Ed.), Reducing Prejudice and Discrimination (pp. 23-45).Lawrence Erlbaum Associates.

[62] Strabac, Z., \& Listhaug, O. (2008). Anti-Muslim Prejudice in Europe: A Multilevel Analysis of Survey Data from 30 Countries. Social Science Research, 37 (1), 268-286.

[63] Wyman, M., \& Snyder, M. (1997). Attitudes toward "Gays in the military": A functional perspective. Journal of Applied Social Psychology, 27, 306-329. 